ISSN 1816-6075 (Print), 1818-0523 (Online)

\title{
A Brief Discussion on Supply Chain Management in Construction Industry
}

\author{
Tasnia Hassan Nazifa ${ }^{1}$, Sarajul Fikri Mohaed ${ }^{2}$, Abdul Bari Amin ${ }^{3 *}$ \\ ${ }^{1}$ Faculty of Built Environment, UTM, Skudai 81310, Johor Bahru, Malaysia \\ ${ }^{2}$ Faculty of Civil Engineering, UTM, Skudai 81310, Johor Bahru, Malaysia \\ ${ }^{3}$ University of Bridgeport, Bridgeport, CT 06604, USA \\ abamin610@gmail.com
}

\begin{abstract}
The importance of supply chain management (SCM) has been mentioned extensively within the scientific literature, particularly within the context of up companies' performance. Since the construction industry could be a key social and economic activity of each country, the implication of SCM methods is taken into account useful in achieving higher competitiveness of construction companies and construction sector as a full. Construction may be a worldwide activity with several special characteristics and it includes comes of dramatically differing types, sizes and complexities. Though the present literature suggests that the generic supply chains ought to be straightforward and linear, the fact within the construction sector is sort of completely different - a myriad of construction supply chains associated markets ought to be integrated by any construction firm once it delivers an answer to a finish customer/client. So the aim of this paper, so as steering for future analysis associated with supply chains in construction, is to review existing analysis and synthesize main approaches and findings. especially, this review seeks to screen existing studies (published in amount 2010-2018 mistreatment Pro Quest database) with respect to their a) level of research, b) analysis focus, c) variety of study/paper, d) the sample used, e) analyzed relationships, and f) the various varieties of construction subjects that are coated and linked into supply chains.
\end{abstract}

Keywords: Construction Firm's Performance, Construction Industry, Supply Chain Management, SCM, Literature Review 


\section{Introduction}

There is little question that construction sector invariably includes a sturdy impact on the whole economy of each country, which it's a worldwide activity with several special characteristics compared with different economic activities. It is the largest economic industry in the world (Ahmed, Islam, Hoque, \& Hossain, 2018). So as to enhance performance and productivity in construction sector, recent studies have highlighted the importance of adoption effective supply chain management (SCM) at intervals construction firms.

SCM is an idea that started within the manufacturing trade. It's seen as a rigorous innovation that's designed on previous changes like Total Quality Management (TQM) and Just-in-time (JIT) (Segerstedt \& Olofsson, 2010). In step with (Mentzer et al., 2001) the supply chain is "the network of organizations that square measure concerned, through upstream and downstream linkages, within the completely different processes and activities that manufacture worth within the kind of product and services within the hands of the last word client." Equally, a supply chain has been conceptualized as "a system whose constituent components embody materials supplies, production facilities,

Distribution services and customers connected via the feed forward flow of materials and also the feedback flow of information" (Croom, Romano, \& Giannakis, 2000). However since the development sector includes comes of dramatically differing kinds, sizes and complexities and there's conjointly a high degree of subcontracting at intervals the business, the definition of construction supply chain may be a bit a lot of complicated. First of all, it is necessary to outline and perceive relationships between clients, consultants, contractors and subcontractors. Saad et al. (Saad, Jones, \& James, 2002) investigated styles of these relationships in terms of the degree of collaboration and integration within the amount between 1960 and 2000 that is shown in Figure 1. 


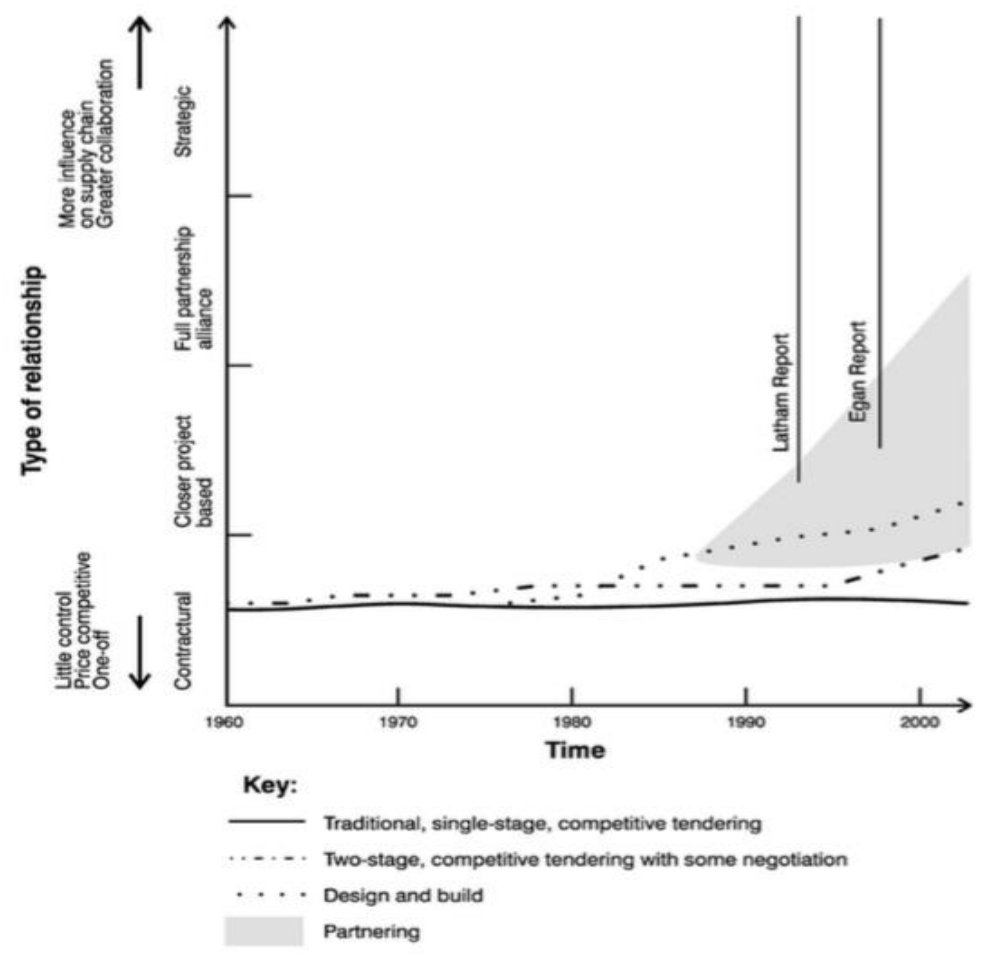

Fig. 1: Type of relationships in the construction industry (Saad et al., 2002)

In Figure 1 is shown that the standard single-stage approach to procure still dominated the approach of construction purchasers. Various acquisition approaches, like "two-stage competitive tendering", "Design and Built", "Management Contracting" and "Construction Management" represent some variations in relationships and roles between partners. The relationships mentioned on top of are literally the term best-known in construction sector as partnering that was the idea of development of SCM. Gil et al. (Gil, Gangopadhyay, Zhou, Gordon, \& Nayak, 2010)) defines partnering as follows:

"Partnering involves two or more organizations operating along to enhance performance through agreeing mutual objectives, explanation the way of partitioning any disputes and committing themselves to continuous improvement, measurement progress and sharing the gains".

SCM in construction is additional developed style of partnering and nowadays 
there's obvious progress towards the adoption of the principles of SCM inside construction sector. In recent years, a tiny low however increasing variety of construction organizations began to adopt SCM ways in recent years to enhance their performance, however Papadopoulos et al. (Papadopoulos, Zamer, Gayialis, $\&$ Tatsiopoulos, 2016)expressed that there's a growing awareness of the requirement for changes inside the construction industry, specifically with respect to its current business processes.

The aim of this paper, so as provide to produce steerage for future analysis associated with supply chains in construction, is to review existing analysis and synthesize main approaches and findings. specially, this review seeks to screen existing studies (published in period 2010-2018 exploitation Pro Quest database) with respect to their a) level of research, b) analysis focus, c) style of study/paper, d) the sample used, e) analyzed relationships, and f) the various styles of construction subjects that are covered and connected into supply chains. The paper is unionized in four sections. In Section a pair of the construction supply chain landscape are shortly represented and a few definitions of supply chain management in construction industry are examined. Section 3 identifies the various bodies of literature during which construction supply chain studies have emerged thus far, whereas Section 4 presents the results of literature review in keeping with the abovementioned criteria and provides some conclusions we will draw from obtained results.

\section{The Construction Supply Chain Landscape}

As we tend to mentioned higher than, the construction industry has several special characteristics. It's usually argued that the construction industry is exclusive within the approach that it establishes comes to deliver one-off merchandise (Krishnakumar \& Kuriakose, 2016), therefore a definition of construction supply chain differs from the origins. According to Xue rt al. (Xue, $\mathrm{Li}$, Shen, \& Wang, 2005) there are three sorts of construction supply chain: 
- The first supply chain - that delivers the materials that are incorporated into the ultimate construction product,

- The support chain - that provides instrumentation, experience and materials that facilitate construction, and

- The human resource supply chain - that involves the availability of labour.

The supply chain idea is usually closely connected with the production method inside industry. Figure 2 presents a schematic read of the method that's created of the operational activities of production inside construction sector.

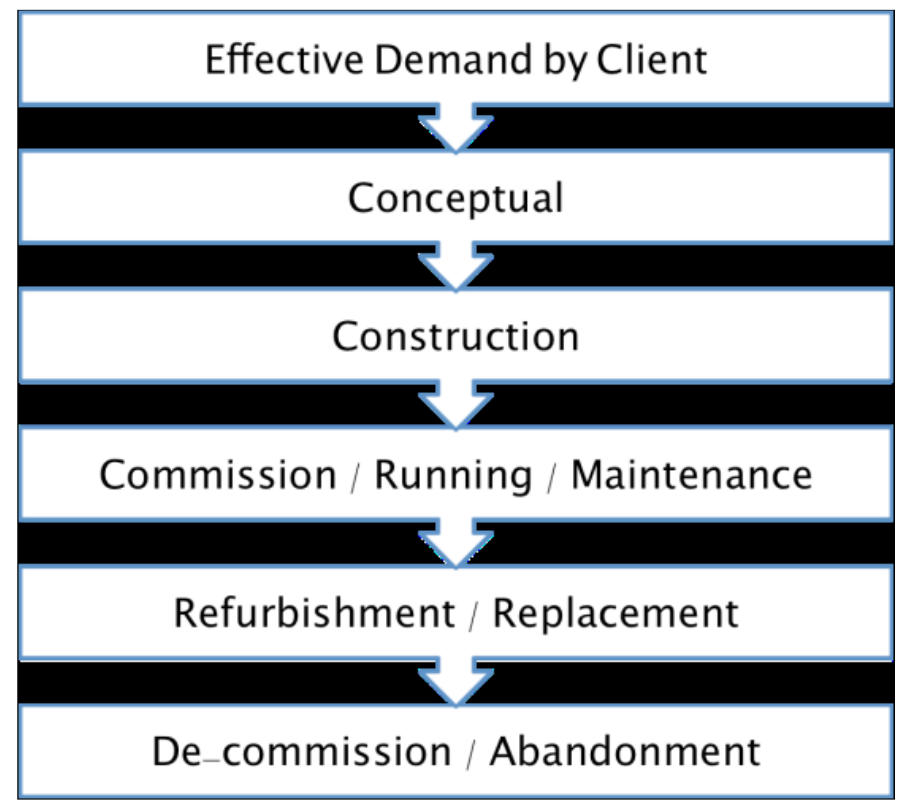

Fig. 2: Process chain of operational activities in construction (Croxton, GarciaDastugue, Lambert, \& Rogers, 2001)

The process shown in the Figure 2. is often explained as a supply chain and can be cyclical whereby several repetitions of the process are undertaken as facilities are modernized or replaced; or can terminate as is the case with many one-off private developments (Croxton et al., 2001). (Ahmed, 2018; Papadopoulos et al., 2016) suggest a "typical" construction supply chain (Figure $3)$. 


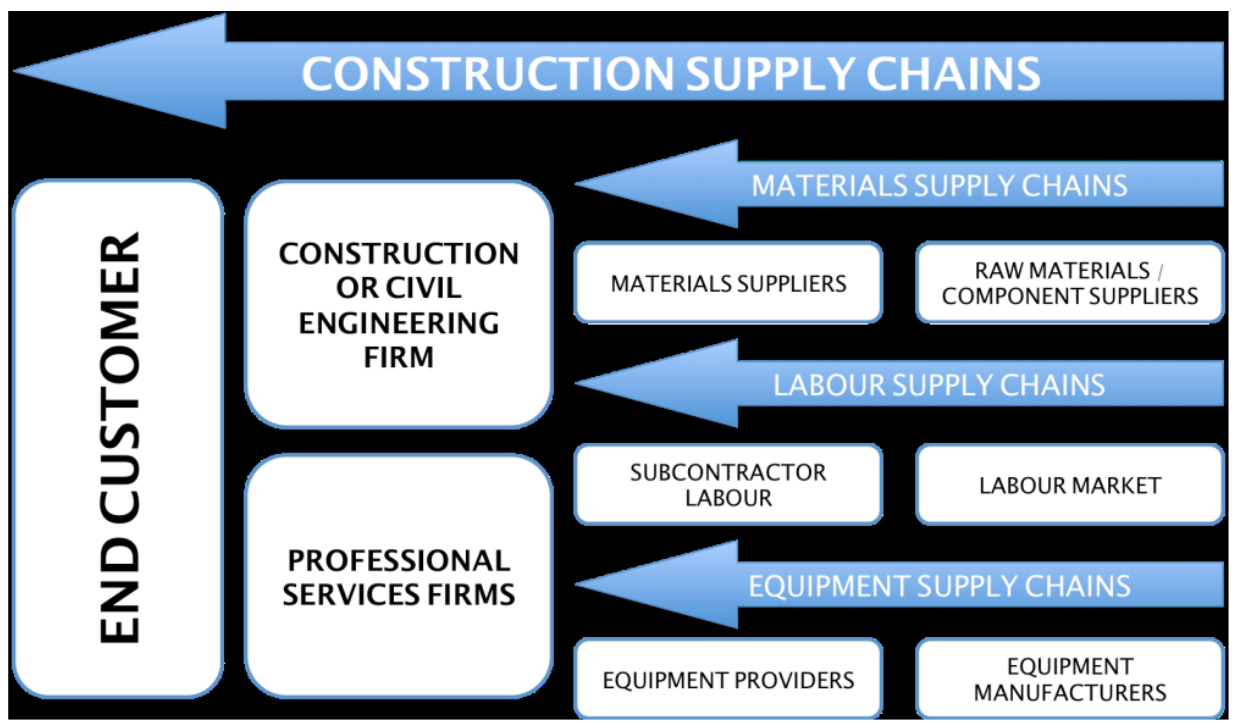

Fig. 3: The myriad of construction supply chains (Papadopoulos et al., 2016)

In the construction industry it's the consumer who takes the initiative to start out a construction project, and this results in the frequent conceptualization of the construction supply chain as a method expressly beginning and ending with the top user as shows Figure three. The stage end customer includes all customers of construction comes. These clients generally source their construction necessities from extremely competitive construction supply markets that the construction project provides the desired practicality to support their business. Moreover, construction or technology firm includes all technology and construction companies that deliver comes to the top client. These companies play the 'integrating' role for all the constituent construction supply chains and generally operate at intervals an extremely competitive marketplace. Skilled services companies includes all skilled services companies that offer engineering, design, planning etc.

It has become that the most important characteristic of the construction supply chain is that every consumer represents distinctive client with unique necessities. And therefore the construction supply chain have to comply with that so as to has simpler and additional economical. The dearth of a universal definition of 
construction supply chain management is partially thanks to the manner the idea of the supply chain has been developed. Such, the idea of construction supply chain has been studied type totally different views at intervals different relevant bodies of the literature, as are represented within the next section.

\section{Bodies of Literature Associated with Construction Supply Chain}

Trying to clarify methodology and helping in making an agenda for future analysis, we present a content summary of the prevailing literature on construction supply chains. We've got started out an indicative delineation in Table 1, identifying the analysis issues at intervals every of the six areas that we have identified within the existing literature to relate to the sector of construction supply chain.

Table 1: Principal component bodies of construction supply chain literature

\begin{tabular}{|c|c|}
\hline $\begin{array}{l}\text { Supply Chain Management } \\
\text { - An examination of a modular } \\
\text { supply chain } \\
\text { - The role of supply chain } \\
\text { management in construction } \\
\text { - Construction supply chain } \\
\text { collaboration and management } \\
\text { - Success factors in } \\
\text { implementation of strategic } \\
\text { partnerships } \\
\text { ICT systems in construction } \\
\text { supply chain management } \\
\text { - Supply chain management and } \\
\text { risks in the construction industry } \\
\text { Safety Decision Points in the } \\
\text { Construction Supply Chain } \\
\text { McKinsey } 7 S \text { Model for Supply } \\
\text { Chain Management of Local } \\
\text { SMEs Construction Business } \\
\text { Demand uncertainty in } \\
\text { construction supply chains }\end{array}$ & 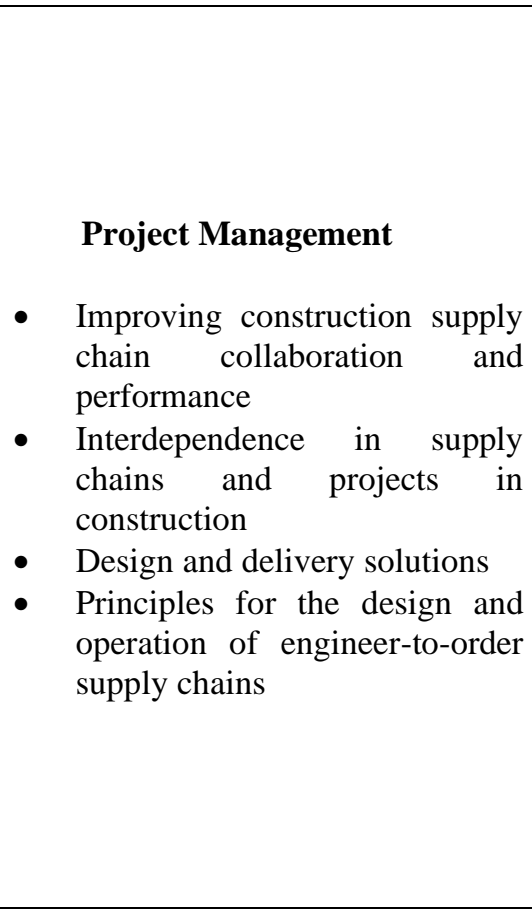 \\
\hline Sustainability & \\
\hline
\end{tabular}




\begin{tabular}{|c|c|}
\hline 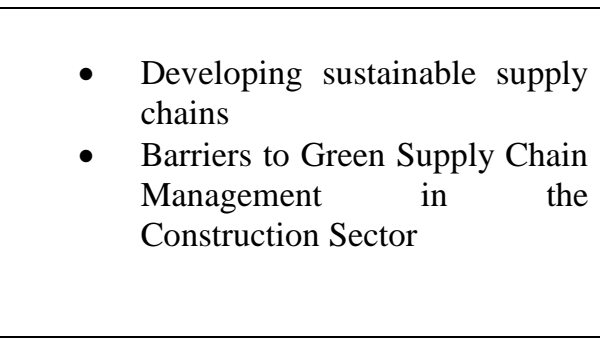 & $\begin{array}{l}\text { Knowledge Management } \\
\text { - Supply chain capital in } \\
\text { construction industry } \\
\text { - Organizational learning } \\
\text { Generative Mechanisms of the } \\
\text { Adoption of Logistics } \\
\text { Innovation }\end{array}$ \\
\hline 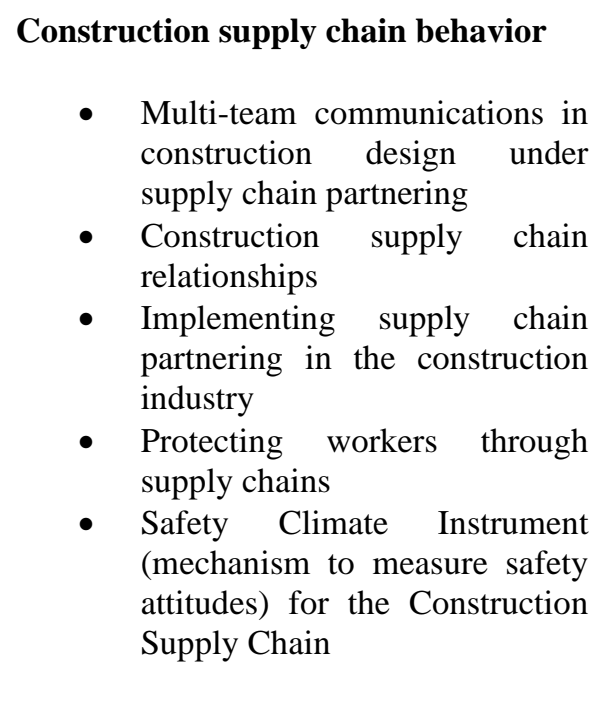 & $\begin{array}{l}\text { Special scope of construction } \\
\text { - } \quad \text { Tunneling construction project's } \\
\text { supply chain } \\
\text { - Construction supply chain in the } \\
\text { public procurement } \\
\text { - Construction supply chain in the } \\
\text { industrialized construction } \\
\text { projects } \\
\text { - Supply chain integration in the } \\
\text { construction and shipbuilding } \\
\text { industries } \\
\text { Hydropower } \\
\text { Construction Supply Chain } \\
\text { Off-site precast concrete } \\
\text { production as a case study for } \\
\text { construction supply chain }\end{array}$ \\
\hline
\end{tabular}

In this review, we didn't only concentrate on applying the content analysis to the literature, however we have a tendency to additionally involving with screening and describing the analytical details of existing studies so as to find possible future analysis. The matrix shown in Table 2 has been obtained by combining these two dimensions and it'll be accustomed summarize the placement of publications in terms of the analysis subject and with respect to the elements of exchange that they take into account. 
Table 2: Construction supply chain content matrix

\begin{tabular}{|c|c|c|c|c|}
\hline Author & $\begin{array}{l}\text { Research } \\
\text { subject }\end{array}$ & $\begin{array}{l}\text { Research } \\
\text { method }\end{array}$ & Sample & Relationship \\
\hline $\begin{array}{l}\text { (Erik Eriksson, } \\
2010 \text { ) }\end{array}$ & $\begin{array}{l}\text { Improving } \\
\text { construction } \\
\text { supply chain } \\
\text { collaboration } \\
\text { and } \\
\text { performance }\end{array}$ & Empirical & $\begin{array}{l}\text { The three } \\
\text { surveys } \\
\text { (responded to } \\
\text { by 26, } 29 \text { and } \\
32 \text { project } \\
\text { participants), } \\
\text { the three } \\
\text { workshops } \\
\text { (attended by } \\
15-20 \\
\text { participants), } \\
12 \text { interviews }\end{array}$ & $\begin{array}{l}\text { Several aspects } \\
\text { facilitate the } \\
\text { achievement of } \\
\text { more than one } \\
\text { core element }\end{array}$ \\
\hline $\begin{array}{l}\text { (Segerstedt \& } \\
\text { Olofsson, 2010) }\end{array}$ & $\begin{array}{l}\text { Interdependenc } \\
\mathrm{e} \quad \text { in supply } \\
\text { chains and } \\
\text { projects in } \\
\text { construction }\end{array}$ & Case study & $\begin{array}{l}\text { The } \\
\text { plasterboard } \\
\text { supply chain }\end{array}$ & - \\
\hline $\begin{array}{l}\text { (Shukor, } \\
\text { Mohammad, } \\
\text { Mahbub, \& } \\
\text { Ismail, 2011). }\end{array}$ & $\begin{array}{l}\text { How } \\
\text { construction } \\
\text { design under } \\
\text { supply chain } \\
\text { partnering can } \\
\text { be improved } \\
\text { through } \\
\text { communication }\end{array}$ & Empirical & $\begin{array}{lr}\begin{array}{l}\text { One } \\
\text { study, case } \\
\text { rounds }\end{array} \\
\text { two } \\
\text { questionnaire } \\
\text { survey } \\
\text { answers) }\end{array}$ & $\begin{array}{l}\text { Partnering can } \\
\text { eliminate many } \\
\text { communication } \\
\text { barriers and has } \\
\text { a positive } \\
\text { impact on } \\
\text { social } \\
\text { collaboration in } \\
\text { the construction } \\
\text { design process }\end{array}$ \\
\hline $\begin{array}{l}\text { (Meng, Sun, \& } \\
\text { Jones, 2011) }\end{array}$ & $\begin{array}{l}\text { Research } \\
\text { review on } \\
\text { construction } \\
\text { supply chain } \\
\text { relationships }\end{array}$ & $\begin{array}{l}\text { Conceptua } \\
1\end{array}$ & & \\
\hline $\begin{array}{l}\text { (Doran \& } \\
\text { Giannakis, } \\
\text { 2011) }\end{array}$ & $\begin{array}{l}\text { The } \\
\text { establishment } \\
\text { and } \\
\text { implementation } \\
\text { of an } \\
\text { aggregated strategic } \\
\text { alliance and its } \\
\text { success factors }\end{array}$ & Case study & $\begin{array}{l}\text { Strategic } \\
\text { alliance by ten } \\
\text { partners }\end{array}$ & $\begin{array}{l}\text { Centralized } \\
\text { communication } \\
\text {, efficient IT } \\
\text { support and } \\
\text { trust among the } \\
\text { partners are } \\
\text { shown to be } \\
\text { major factors } \\
\text { contributing to } \\
\text { the success of } \\
\text { the alliance }\end{array}$ \\
\hline
\end{tabular}




\begin{tabular}{|c|c|c|c|c|}
\hline (Meng, 2012) & $\begin{array}{l}\text { Hydropower } \\
\text { development } \\
\text { construction } \\
\text { supply chain }\end{array}$ & Simulation & $\begin{array}{l}\text { Three supply } \\
\text { chains }\end{array}$ & - \\
\hline $\begin{array}{l}\text { (Lingard, } \\
\text { Cooke, \& } \\
\text { Blismas, 2012) }\end{array}$ & $\begin{array}{l}\text { The degree to } \\
\text { which supply } \\
\text { chain practices } \\
\text { are aligned with } \\
\text { modular } \\
\text { construction }\end{array}$ & Case study & $\begin{array}{l}\text { Five modular } \\
\text { construction } \\
\text { supply chain }\end{array}$ & \\
\hline $\begin{array}{l}\text { (Aloini, Dulmin, } \\
\text { Mininno, \& } \\
\text { Ponticelli, 2012) }\end{array}$ & $\begin{array}{l}\text { Identifying } \\
\text { variables } \\
\text { impacting the } \\
\text { productivity of } \\
\text { tunneling } \\
\text { construction } \\
\text { projects }\end{array}$ & Case study & $\begin{array}{l}\text { One tunnel } \\
\text { project }\end{array}$ & \\
\hline $\begin{array}{l}\text { (Sarhan \& Fox, } \\
\text { 2013) }\end{array}$ & $\begin{array}{l}\text { Establishing } \\
\text { public } \\
\text { construction } \\
\text { supply chain }\end{array}$ & $\begin{array}{l}\text { Action } \\
\text { research }\end{array}$ & $\begin{array}{l}\text { One public } \\
\text { project } \\
\text { (school estate) }\end{array}$ & \\
\hline $\begin{array}{l}\text { (Ali, Al-Sulaihi, } \\
\text { \& Al-Gahtani, } \\
\text { 2013) }\end{array}$ & $\begin{array}{l}\text { The key safety } \\
\text { decision points } \\
\text { in the } \\
\text { construction } \\
\text { supply chain }\end{array}$ & Case study & $\begin{array}{l}\text { Large } \\
\text { wastewater } \\
\text { overflow tank }\end{array}$ & \\
\hline (Eriksson, 2013) & $\begin{array}{l}\text { Investigating } \\
\text { the risk factors } \\
\text { affecting the } \\
\text { implementation } \\
\text { of SCM } \\
\text { principles }\end{array}$ & $\begin{array}{l}\text { Conceptua } \\
1\end{array}$ & $\begin{array}{l}140 \text { research } \\
\text { articles }\end{array}$ & \\
\hline (Fewings, 2013) & $\begin{array}{l}\text { Evaluating the } \\
\text { barriers to the } \\
\text { adoption of } \\
\text { green supply } \\
\text { chain } \\
\text { management }\end{array}$ & Empirical & $\begin{array}{l}32 \text { barriers to } \\
\text { the adoption } \\
\text { of GSCM } \\
\text { were } \\
\text { classified by } \\
11 \\
\text { participants in } \\
3 \text { workshops }\end{array}$ & $\begin{array}{l}\text { Identified } \\
\text { external and } \\
\text { internal factors } \\
\text { that are critical } \\
\text { barriers }\end{array}$ \\
\hline $\begin{array}{l}\text { (Fulford \& } \\
\text { Standing, 2014) }\end{array}$ & $\begin{array}{l}\text { Developing an } \\
\text { innovative crew } \\
\text { allocation } \\
\text { system }\end{array}$ & Case study & $\begin{array}{l}\text { Off-site } \\
\text { precast } \\
\text { concrete } \\
\text { production }\end{array}$ & \\
\hline
\end{tabular}




\begin{tabular}{|c|c|c|c|c|}
\hline $\begin{array}{l}\text { (Govindan, } \\
\text { Kaliyan, } \\
\text { Kannan, \& Haq, } \\
\text { 2014) }\end{array}$ & $\begin{array}{l}\text { Exploring the } \\
\text { theory and } \\
\text { current practice } \\
\text { of } \\
\text { organizational } \\
\text { learning in UK } \\
\text { construction } \\
\text { supply chains }\end{array}$ & Empirical & $\begin{array}{l}\text { Interviews } \\
\text { with } 7 \\
\text { construction } \\
\text { companies }\end{array}$ & \\
\hline $\begin{array}{l}\text { (van Vught \& } \\
\text { van Weele, } \\
2015)\end{array}$ & $\begin{array}{l}\text { The impact of } \\
\text { demand } \\
\text { uncertainty on } \\
\text { supply chain } \\
\text { performance }\end{array}$ & Simulation & $\begin{array}{l}2 \text { material } \\
\text { distribution } \\
\text { companies }\end{array}$ & $\begin{array}{l}\text { Lead times are } \\
\text { particularly } \\
\text { sensitive to } \\
\text { fluctuations } \\
\text { under } \\
\text { conditions of } \\
\text { low demand } \\
\text { and higher } \\
\text { inventory costs } \\
\text { result in a } \\
\text { negative } \\
\text { exponential } \\
\text { relationship } \\
\text { between } \\
\text { increasing } \\
\text { demand and } \\
\text { cost efficiency }\end{array}$ \\
\hline $\begin{array}{l}\text { (Dadhich, } \\
\text { Genovese, } \\
\text { Kumar, \& } \\
\text { Acquaye, 2015) }\end{array}$ & $\begin{array}{l}\text { Improving } \\
\text { processes } \\
\text { adopted by a } \\
\text { small/medium } \\
\text { enterprise } \\
\text { (SME) } \\
\text { contractor for } \\
\text { the control of } \\
\text { defects in its } \\
\text { supply chain }\end{array}$ & $\begin{array}{l}\text { Action } \\
\text { research }\end{array}$ & $\begin{array}{l}6 \text { different } \\
\text { supply chain } \\
\text { participants } \\
\text { (architect, } \\
\text { services } \\
\text { designers, } \\
\text { contracts } \\
\text { director, site } \\
\text { manager, } \\
\text { subcontractor } \\
\text { s and material }\end{array}$ & \\
\hline $\begin{array}{l}\text { (Krishnakumar } \\
\& \quad \text { Kuriakose, } \\
\text { 2016) }\end{array}$ & $\begin{array}{l}\text { The integration } \\
\text { of information } \\
\text { flows in relation } \\
\text { to material } \\
\text { management } \\
\text { throughout the } \\
\text { construction } \\
\text { industry supply- } \\
\text { chain }\end{array}$ & Case study & $\begin{array}{l}\text { Industrialized } \\
\text { construction } \\
\text { project }\end{array}$ & \\
\hline
\end{tabular}




\begin{tabular}{|c|c|c|c|c|}
\hline $\begin{array}{l}\text { (Papadopoulos } \\
\text { et al., 2016) }\end{array}$ & $\begin{array}{l}\text { The McKinsey } \\
7 \mathrm{~S} \text { model to } \\
\text { study the } \\
\text { successful } \\
\text { business } \\
\text { strategy of } \\
\text { supply chain } \\
\text { management }\end{array}$ & Empirical & $\begin{array}{l}\text { Local SME } \\
\text { construction } \\
\text { shops }\end{array}$ & $\begin{array}{l}\text { Strategy was } \\
\text { scored highly }\end{array}$ \\
\hline $\begin{array}{l}\text { (Akan, Dhavale, } \\
\& \text { Sarkis, 2017) }\end{array}$ & $\begin{array}{l}\text { Implementation } \\
\text { of SCP as } \\
\text { understanding } \\
\text { managerial and } \\
\text { intra- } \\
\text { organizational } \\
\text { dynamics }\end{array}$ & $\begin{array}{l}\text { Action } \\
\text { research }\end{array}$ & $\begin{array}{l}\text { Dutch } \\
\text { housing } \\
\text { association }\end{array}$ & \\
\hline $\begin{array}{l}\text { (Mathiyazhagan } \\
\text { \& Datta, Singla, } \\
\text { Krishnamoorthi, } \\
\text { 2018) }\end{array}$ & $\begin{array}{l}\text { The impact of } \\
\text { product } \\
\text { modularity on } \\
\text { Supply Chain } \\
\text { (SC) integration }\end{array}$ & Case study & $\begin{array}{l}\text { Five } \\
\text { companies } \\
\text { The higher the } \\
\text { product } \\
\text { modularity, } \\
\text { the lower the } \\
\text { SC integration }\end{array}$ & \\
\hline $\begin{array}{l}\text { (Nguyen et al., } \\
\text { 2018) }\end{array}$ & $\begin{array}{l}\text { Identifying the } \\
\text { factors } \\
\text { supporting the } \\
\text { effective } \\
\text { management of } \\
\text { health and } \\
\text { safety }\end{array}$ & Case study & $\begin{array}{l}\text { Two case } \\
\text { studies on one } \\
\text { contractor }\end{array}$ & \\
\hline
\end{tabular}

As it can be seen from the matrix, $44 \%$ of the analyzed papers present case studies, $23 \%$ are empirical, $15 \%$ are theoretical, $11 \%$ are action researches and $7 \%$ are simulations. An overview of the studies regard to the project subjects or construction company, they cover is presented in Table 3.

Table 3: Construction project subjects in construction supply chain studies

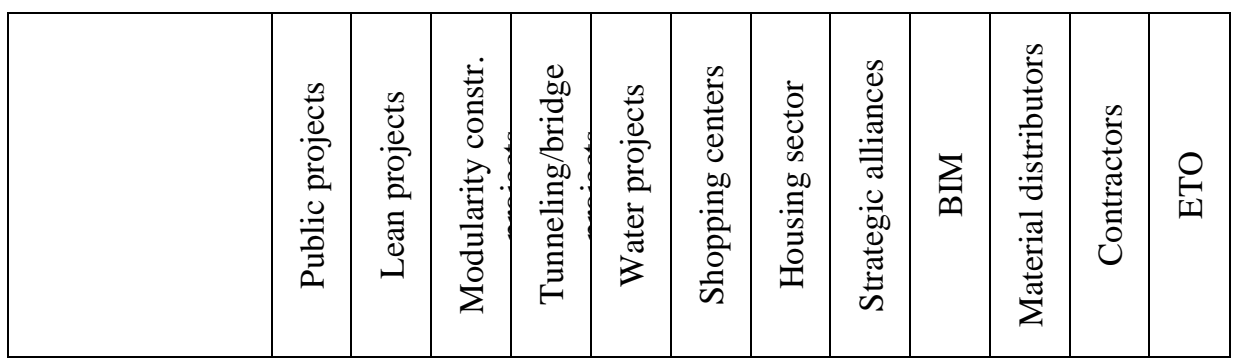




\begin{tabular}{|c|c|c|c|c|c|c|c|c|c|c|c|c|}
\hline $\begin{array}{l}\text { (Erik Eriksson, } \\
2010)\end{array}$ & & $\sqrt{ }$ & & & & & & & & & & \\
\hline $\begin{array}{l}\text { (Segerstedt \& } \\
\text { Olofsson, 2010) }\end{array}$ & & & $\sqrt{ }$ & & & & & & & & & \\
\hline $\begin{array}{l}\text { (Shukor et al., } \\
\text { 2011). }\end{array}$ & & & & & & & & & & $\sqrt{ }$ & & \\
\hline $\begin{array}{l}\text { (Meng et al., } \\
2011)\end{array}$ & & & & & & & & & & & $\sqrt{ }$ & \\
\hline $\begin{array}{l}\text { Doran \& } \\
\text { Giannakis, } \\
\text { 2011) }\end{array}$ & & & & $\sqrt{ }$ & & & & & & & & \\
\hline (Meng, 2012) & & & & & & $\sqrt{ }$ & & & & & & \\
\hline $\begin{array}{l}\text { (Lingard et al., } \\
\text { 2012) }\end{array}$ & & & & & & & & & & & $\sqrt{ }$ & \\
\hline $\begin{array}{l}\text { (Aloini et al., } \\
\text { 2012) }\end{array}$ & & & & & & & & & & & $\sqrt{ }$ & \\
\hline $\begin{array}{l}\text { (Sarhan \& Fox, } \\
\text { 2013) }\end{array}$ & $\sqrt{ }$ & & & & & & & & & & & \\
\hline (Ali et al., 2013) & & & & & & & $\sqrt{ }$ & & & & & \\
\hline $\begin{array}{l}\text { (Eriksson, } \\
\text { 2013) }\end{array}$ & & & & $\sqrt{ }$ & & & & & & & & \\
\hline (Fewings, 2013) & & & & & & & & $\sqrt{ }$ & & & & \\
\hline $\begin{array}{lr}\text { (Fulford } \quad \& \\
\text { Standing, 2014) }\end{array}$ & & & & & & & & $\sqrt{ }$ & & & & \\
\hline $\begin{array}{l}\text { (Govindan et } \\
\text { al., 2014) }\end{array}$ & & & & $\sqrt{ }$ & & & & & & & & \\
\hline $\begin{array}{l}\text { (van Vught \& } \\
\text { van Weele, } \\
2015)\end{array}$ & & & & & & & & & & & $\sqrt{ }$ & \\
\hline $\begin{array}{l}\text { (Dadhich et al., } \\
\text { 2015) }\end{array}$ & & $\sqrt{ }$ & & & & & & & & & & \\
\hline $\begin{array}{l}\text { (Krishnakumar } \\
\& \quad \text { Kuriakose, } \\
\text { 2016) }\end{array}$ & & & & & $\sqrt{ }$ & & & & & & & \\
\hline $\begin{array}{l}\text { (Papadopoulos } \\
\text { et al., 2016) }\end{array}$ & & & & & & & & & & & & $\sqrt{ }$ \\
\hline $\begin{array}{l}\text { (Akan et al., } \\
\text { 2017) }\end{array}$ & & & & & & & & $\sqrt{ }$ & & & & \\
\hline $\begin{array}{l}\text { (Mathiyazhagan } \\
\text { et al., 2018) }\end{array}$ & & & & $\sqrt{ }$ & & & & & & & & \\
\hline $\begin{array}{l}\text { (Nguyen et al., } \\
2018 \text { ) }\end{array}$ & & & & & & & & & & $\sqrt{ }$ & & \\
\hline
\end{tabular}

Summarized results with respect to the construction project subjects veiled by 
present construction supply chain studies show that mostly of research papers target their research on contractors companies and also on material distributors. According to construction projects, we find that an equal number of studies research housing project, tunneling/bridge projects or public projects.

\section{Conclusion}

Because SCM implementation within the housing industry has been scattered and partial to this point, the intention of this review paper was to present an outline of the context and focus of previous supply chain studies that are set inside a construction context, and to produce a reference guide for more analysis. The authors shall update and extend this literature review, and therefore any provision of knowledge associated with construction supply chains is welcome and extremely appreciated.

One of the foremost important findings from our literature analysis has been the relative lack of theoretical work in this field in comparison to empirical based mostly studies. More research may aim to check the work of supply chain management methods with existing construction management methods. Specifically, because of the fragility of the many construction systems, future studies could shift specific focus the role of supply chain management methods in achieving construction property at the project level and conjointly expand the main focus to supply chain management methods utilized in construction systems.

\section{References}

Ahmed, S. (2018). Barriers to Implementation of Building Information Modeling (BIM) to the Construction Industry: A Review. Journal of Civil Engineering and Construction, 7(2), 107-113. 
Ahmed, S., Islam, H., Hoque, I., \& Hossain, M. (2018). Reality check against skilled worker parameters and parameters failure effect on the construction industry for Bangladesh. International Journal of Construction Management, 110.

Akan, M. Ö. A., Dhavale, D. G., \& Sarkis, J. (2017). Greenhouse gas emissions in the construction industry: An analysis and evaluation of a concrete supply chain. Journal of Cleaner Production, 167, 1195-1207.

Ali, H. A. E. M., Al-Sulaihi, I. A., \& Al-Gahtani, K. S. (2013). Indicators for measuring performance of building construction companies in Kingdom of Saudi Arabia. Journal of King Saud University-Engineering Sciences, 25(2), 125-134.

Aloini, D., Dulmin, R., Mininno, V., \& Ponticelli, S. (2012). Supply chain management: a review of implementation risks in the construction industry. Business Process Management Journal, 18(5), 735-761.

Croom, S., Romano, P., \& Giannakis, M. (2000). Supply chain management: an analytical framework for critical literature review. European journal of purchasing \& supply management, 6(1), 67-83.

Croxton, K. L., Garcia-Dastugue, S. J., Lambert, D. M., \& Rogers, D. S. (2001). The supply chain management processes. The International Journal of Logistics Management, 12(2), 13-36.

Dadhich, P., Genovese, A., Kumar, N., \& Acquaye, A. (2015). Developing sustainable supply chains in the UK construction industry: A case study. International Journal of Production Economics, 164, 271-284.

Doran, D., \& Giannakis, M. (2011). An examination of a modular supply chain: a construction sector perspective. Supply Chain Management: An International Journal, 16(4), 260-270. 
Erik Eriksson, P. (2010). Improving construction supply chain collaboration and performance: a lean construction pilot project. Supply Chain Management: An International Journal, 15(5), 394-403.

Eriksson, P. E. (2013). Exploration and exploitation in project-based organizations: Development and diffusion of knowledge at different organizational levels in construction companies. International Journal of Project Management, 31(3), 333-341.

Fewings, P. (2013). Construction project management: an integrated approach: Routledge.

Fulford, R., \& Standing, C. (2014). Construction industry productivity and the potential for collaborative practice. International Journal of Project Management, 32(2), 315-326.

Gil, R., Gangopadhyay, D., Zhou, J., Gordon, S., \& Nayak, S. (2010). Supply chain management: Google Patents.

Govindan, K., Kaliyan, M., Kannan, D., \& Haq, A. N. (2014). Barriers analysis for green supply chain management implementation in Indian industries using analytic hierarchy process. International Journal of Production Economics, 147, $555-568$.

Krishnakumar, S., \& Kuriakose, L. T. (2016). Supply Chain Management in Construction Industry. International Journal of Scientific Engineering and Research (IJSER), ISSN (Online), 2347-3878.

Lingard, H., Cooke, T., \& Blismas, N. (2012). Do perceptions of supervisors' safety responses mediate the relationship between perceptions of the organizational safety climate and incident rates in the construction supply chain? Journal of Construction Engineering and Management, 138(2), 234-241. 
Mathiyazhagan, K., Datta, U., Singla, A., \& Krishnamoorthi, S. (2018). Identification and prioritization of motivational factors for the green supply chain management adoption: case from Indian construction industries. OPSEARCH, $55(1), 202-219$.

Meng, X. (2012). The effect of relationship management on project performance in construction. International Journal of Project Management, 30(2), 188-198.

Meng, X., Sun, M., \& Jones, M. (2011). Maturity model for supply chain relationships in construction. Journal of Management in Engineering, 27(2), 97105.

Mentzer, J. T., DeWitt, W., Keebler, J. S., Min, S., Nix, N. W., Smith, C. D., \& Zacharia, Z. G. (2001). Defining supply chain management. Journal of Business logistics, 22(2), 1-25.

Nguyen, P. T., Nguyen, V. N., Pham, L. H., Nguyen, T. A., Le, Q., Nguyen, H. T. T., \& Huynh, V. D. B. (2018). Application of supply chain management in construction industry. Advances in science and technology-research journal, 12(2), 11-19.

Papadopoulos, G. A., Zamer, N., Gayialis, S. P., \& Tatsiopoulos, I. P. (2016). Supply Chain Improvement in Construction Industry. Universal Journal of Management, 4(10), 528-534.

Saad, M., Jones, M., \& James, P. (2002). A review of the progress towards the adoption of supply chain management (SCM) relationships in construction. European journal of purchasing \& supply management, 8(3), 173-183.

Sarhan, S., \& Fox, A. (2013). Barriers to implementing lean construction in the UK construction industry. The Built \& Human Environment Review. 
Segerstedt, A., \& Olofsson, T. (2010). Supply chains in the construction industry. Supply Chain Management: An International Journal, 15(5), 347-353.

Shukor, A. A., Mohammad, M., Mahbub, R., \& Ismail, F. (2011). Supply chain integration in industralised building system in the malaysian construction industry. The Built \& Human Environment Review, 4(1), 108-121.

van Vught, R., \& van Weele, A. (2015). Managing supply chain relationships in construction industry: compete or collaborate? Paper presented at the conference; IPSERA; 2015-03-29; 2015-04-01.

Xue, X., Li, X., Shen, Q., \& Wang, Y. (2005). An agent-based framework for supply chain coordination in construction. Automation in construction, 14(3), 413-430. 